\title{
Evaluation of Industrial Workplace Exposure to Metal Fumes using Toenail as Bio-Indicator
}

\section{Siti Farhana Zainal Bakri ${ }^{1,2^{*}}$, Azian Hariri ${ }^{2}$, Marzuki Ismail ${ }^{3}$, Amir Abdullah Muhamad Damanhuri ${ }^{4}$}

${ }^{1}$ DRB-HICOM University of Automotive Malaysia,

Faculty of Engineering and Technology, Pekan, 26607, MALAYSIA

${ }^{2}$ Universiti Tun Hussein Onn Malaysia,

Faculty of Mechanical and Manufacturing Engineering, Batu Pahat, 86400, MALAYSIA

${ }^{3}$ Universiti Malaysia Terengganu,

School of Ocean Engineering, Kuala Terengganu, 21300, MALAYSIA

${ }^{4}$ Universiti Teknikal Malaysia Melaka,

Faculty of Engineering Technology Mechanical and Manufacturing, Durian Tunggal, 76100, MALAYSIA

*Corresponding Author

DOI: https://doi.org/10.30880/ijie.2019.11.05.018

Received 5 March 2019; Accepted 26 March 2019; Available online 10 August 2019

\begin{abstract}
The toxic gaseous generated from welding process contained heavy metals that induce various cancers and diseases. Exposure to this toxic fume is associated with the occurrence of lung cancer and worker that exposed to this situation is considered as a high-risk group. This study aims to investigate the amounts of heavy metals concentration in the breathing zone and toenail samples of 36 individuals from automotive related industries in Malaysia that were classified as an exposed group (welders) and non-exposed group (office workers) by crosssectional research design. Personal air sample and mixed cellulose ester (MCE) filters were used to collect the welding fumes while toenail samples from all 10 toes of each subject for biomonitoring. Collected samples were digested, and analyzed to evaluate the levels of heavy metals by inductively coupled plasma mass spectrometry (ICP-MS). Eleven heavy metals ( $\mathrm{Al}, \mathrm{Cr}, \mathrm{Mn}, \mathrm{Fe}, \mathrm{Co}, \mathrm{Ni}, \mathrm{Zn}, \mathrm{Cu}, \mathrm{As}, \mathrm{Ag}$, and $\mathrm{Pb}$ ) were measured in all samples; and results showed that the concentrations of $\mathrm{Cr}, \mathrm{Zn}, \mathrm{As}, \mathrm{Ag}$ and $\mathrm{Pb}$ were significantly difference $(\mathrm{P} \leq 0.05)$ for exposed and non-exposed groups. Furthermore, the metal fume exposure generated from different welding types in these three plant shows a similar exposure to the welders. Thus, more attention need to be considered to the working conditions of the exposed group, specifically on providing proper ventilation at the workplace as well as to provide a suitable protective personal devices.
\end{abstract}

Keywords: Carcinogenic metal, toenail biomarker, welding fumes, Malaysia.

\section{Introduction}

Heavy metals are a group of metals and metalloids that normally present naturally, released into the environment by both natural and anthropogenic sources. These are toxic in any state for humans and animals even at low concentration [1]. Most of the non-biodegradable elements are classified as human carcinogenic (known or probable) according to the International Agency for Research on Cancer (IARC) who have a tendency to accumulate in a living organism and may cause adverse health effects either in the long term or continuous exposure [2]. In recent years, 
investigating heavy metal is a continuing concern within global public health. The human exposure has increased dramatically because of a few factors as a result of the heavy metals application in industrial process and product. The metal-based operation in industries such as welding is a point source area that makes the workplace environmental pollution became very prominent. Excessive exposure to heavy metals can lead to a variety of disease and adverse effects due to cellular and tissue damage [3]-[5]. The toxicity of heavy metal can damage the function of body systems and important organ such as lungs, brain, liver, kidney and also can cause neurological degenerative processes [6]. This element able to disturb the important biochemical processes that lead to oxidative damage and has the potential to cause chronic inflammatory disease and cancer [7]. Generally, the heavy metal may enter the human body through inhalation of dust, direct ingestion of soil, water or consumption of vegetable from contaminated fields as well as dermal absorption [8]. However, in an occupational setting, inhalation is the common route of exposure to human. To date, little studies have examined the association between heavy metals concentration in the workplace and human bodyusing toenail as a biomarker. Thus, the aim of this paper is to explore the relationship between the existences of heavy metal concentrations in the workplace environment with heavy metal found in the worker's body.

\section{Methodology}

\subsection{Study Population}

The target population of this study is among Malaysian male welders with at least one year of experience as a welder (exposed group) and administrative worker who worked in the same industries and did not expose to any welding fumes (non-exposed group) in Peninsular Malaysia. The entire involved participant comes from three different automotive-related plants located in both Malacca and Pahang areas. These industries have the same business that related to the manufacture and assembly of the automotive-related component. Participants were recruited between October 2016 and April 2018 with a ration of the non-exposed group and exposed group were approximately 1:3. A total of 36 participants have provided biological samples: 27 participants in the exposed group and nine participants (eight males and one female) in the non-exposed group. All study subjects provided toenail samples to assess the body concentrations of heavy metals. Overall, these workers had normal working hours, with the average exposure among welders is $8 \mathrm{hr} /$ day or $40 \mathrm{hr} /$ week.

\subsection{Sample Collection and Analysis}

Samples are collected from each factory to determine a welding fume concentrations in the welding areas by using a personal air pump Gillian 5000 (Sensidyne, USA) with three-piece sampling cassette (SKC Ltd, UK) that equipped with $37 \mathrm{~mm} 0.8 \mu \mathrm{m}$ mixed cellulose ester (MCE) filter and supporting media with $1.7 \mathrm{~L} / \mathrm{min}$ flow rate. The air is collected in the breathing zone in front of the face within 0.2 to $0.3 \mathrm{~m}$ diameters from the nostrils of the welder. For biomonitoring, toenail samples were collected from all 10 toes of each subject by using stainless-steel nail clippers and stored in a labelled envelope. Toenail clippings were analyzed by following a modified version of Method 3050B, USEPA as described in previous research [9], [10]. All filter paper and toenail samples were transferred to the accredited laboratory for analysis by using inductively coupled plasma mass spectrometry (ICP-MS) with microwave digestion method according to ASTM D7439-08 at the Central Laboratory, Universiti Malaysia Pahang. The assessed elements in this research are $\mathrm{Al}, \mathrm{Cr}, \mathrm{Mn}, \mathrm{Fe}, \mathrm{Co}, \mathrm{Ni}, \mathrm{Zn}, \mathrm{Cu}, \mathrm{As}, \mathrm{Ag}, \mathrm{Cd}$, and Pb.

\subsection{Statistical Analysis}

The distribution data had positive skewness and are analyzed using IBM SPSS Statistics for Window version 23 (IBM SPSS Inc., Chicago, IL, USA) and Microsoft Office Excels 2016. The descriptive statistics of age, height, weight, and smoking status are calculated. Mann-Whitney test is used to analyze the significance of the differences between the means concentration of heavy metal in toenail of controls and exposed groups. The Kruskal-Wallis test uses to compare the averages of three different welding type as the independent groups (MIG, spot weld and robotic weld) in the plant. The significance of correlations between parameters (toenail metals levels and airborne metals concentrations) is determined by Spearman's rank correlation coefficient. The interpretation of Spearman's rho is adapted from Dancey and Reidy (2004) [11]. Statistical significance was defined as a p-value of $<0.05$.

\subsection{Ethical Consideration}

The present study approval was taken from a research ethics review committee of International Islamic University Malaysia, Pahang, Malaysia (Ref. ID: IREC 850). Verbal and written informed consent was taken from the participants.

\section{Results and Discussion}

Globally, researchers have reported the adverse health effects from occupational exposure to welding fumes [12][15]. Welders are commonly exposed to carcinogenic metals such as manganese, lead, iron, cadmium, nickel and such that generated by MIG, spot weld and robotic welding [16]-[19]. Frequencies of age, height, weight, and smoking habit 
of the participant are shown in Table 1. The involved participants are 97\% Malay and 3\% Indian with the majority is classified as ever-smokers (current and ex-smokers). A former smoker is those who had smoked for at least one year but not during the last 12 months [20].

Table 1: Demographic data of participated welders and control in biomonitoring.

\begin{tabular}{ccccc}
\hline \multirow{2}{*}{ Group } & \multicolumn{4}{c}{ Variable (mean \pm SD) } \\
\cline { 2 - 5 } & Age $(\mathbf{y r})$ & Height $(\mathbf{c m})$ & Weight $(\mathbf{k g})$ & Ever-Smokers \% \\
\hline Exposed $(\mathrm{N}=27)$ & $27.44 \pm 8.09$ & $1.68 \pm 0.08$ & $68.54 \pm 21.99$ & $85 \%(23)$ \\
Non-exposed $(\mathrm{N}=9)$ & $35.33 \pm 11.26$ & $1.66 \pm 0.06$ & $64.09 \pm 9.79$ & $67 \%(6)$ \\
\hline
\end{tabular}

In overall, the result of heavy metal concentrations in the welding-working environment and the toenail samples are summarized in Table 2. Out of 14-targeted heavy metals, 11 heavy metals were detected by ICP-MS at the welding area samples, while 12 toxic metals are traced in toenail specimens. In the analysed samples, there is no beryllium (Be) and molybdenum (Mo) were detected in both personal sampling and biomarker while none of the cadmium (Cd) elements is traced in three different plants.

Table 2: Summary statistics of heavy metal concentration in the workplace environment $\left(\mathrm{mg} / \mathrm{m}^{3}\right)$ emitted from different welding type and toenail specimens (ug/g) of exposed and non-exposed worker.

\begin{tabular}{|c|c|c|c|c|c|c|c|c|c|c|}
\hline \multicolumn{10}{|c|}{ Toxic Metal Concentration in workplace environment $\left(\mathrm{mg} / \mathrm{m}^{3}\right)$} & \multirow{3}{*}{$\begin{array}{c}\text { PEL } \\
\text { USECHH } \\
\left(\mathrm{mg} / \mathrm{m}^{3}\right)\end{array}$} \\
\hline \multirow{2}{*}{ Metal } & \multicolumn{3}{|c|}{ MIG } & \multicolumn{3}{|c|}{ Spot Weld } & \multicolumn{3}{|c|}{ Robotic Weld } & \\
\hline & $\mathbf{A M}$ & GM & SD & $\mathbf{A M}$ & GM & SD & $\mathbf{A M}$ & GM & SD & \\
\hline Al & 44.35 & 23.81 & 29.37 & 54.54 & 53.42 & 15.54 & 48.38 & 44.92 & 20.88 & 5.00 \\
\hline $\mathbf{C r}$ & 237.78 & 188.86 & 97.38 & 204.69 & 196.16 & 82.70 & 232.30 & 223.96 & 80.27 & 0.50 \\
\hline Mn & 604.25 & 61.09 & 1152.74 & 6.45 & 6.37 & 1.40 & 9.19 & 9.17 & 0.88 & 0.20 \\
\hline $\mathbf{F e}$ & 590.69 & 169.33 & 780.05 & 228.86 & 191.53 & 177.17 & 165.08 & 24.30 & 184.79 & 5.00 \\
\hline Co & 0.38 & 0.17 & 0.26 & 1.03 & 0.89 & 0.72 & 0.54 & 0.51 & 0.22 & 0.10 \\
\hline $\mathbf{N i}$ & 13.46 & 2.56 & 26.81 & 3.29 & 2.97 & 2.00 & 0.89 & 0.83 & 0.35 & 1.50 \\
\hline $\mathrm{Cu}$ & 8.64 & 7.42 & 6.39 & 5.72 & 4.86 & 4.26 & 4.58 & 4.29 & 1.99 & 0.20 \\
\hline $\mathbf{Z n}$ & 11.99 & 6.03 & 11.60 & 8.60 & 5.86 & 8.90 & 8.96 & 7.32 & 5.62 & 5.00 \\
\hline As & 68.94 & 38.74 & 40.01 & 51.58 & 50.66 & 13.68 & 58.58 & 58.20 & 8.38 & 0.01 \\
\hline Ag & 4.73 & 1.65 & 6.78 & 1.62 & 1.56 & 0.62 & 0.43 & 0.41 & 0.15 & 0.10 \\
\hline $\mathbf{P b}$ & 77.21 & 70.46 & 35.48 & 63.09 & 63.09 & 0.42 & 61.38 & 57.21 & 25.50 & 0.05 \\
\hline
\end{tabular}

Toxic Metal Concentration in Toenail (ug/g)

\begin{tabular}{ccccccc}
\hline \multirow{2}{*}{ Metal } & \multicolumn{3}{c}{ Exposed Worker } & \multicolumn{3}{c}{ Non-exposed } \\
\cline { 2 - 7 } & AM & GM & SD & AM & GM & SD \\
\hline Al & 53.11 & 13.87 & 62.24 & 1025.11 & 32.78 & 2338.02 \\
$\mathbf{C r}$ & 118.66 & 52.12 & 217.60 & 1257.63 & 399.02 & 2100.63 \\
$\mathbf{M n}$ & 4.08 & 1.31 & 12.39 & 5.54 & 1.75 & 7.64 \\
$\mathbf{F e}$ & 115.73 & 0.61 & 403.63 & 40.68 & 0.22 & 117.12 \\
$\mathbf{C o}$ & 1.77 & 0.01 & 8.98 & 0.16 & 0.05 & 0.28 \\
$\mathbf{N i}$ & 18.66 & 5.66 & 21.17 & 38.78 & 12.96 & 45.30 \\
$\mathbf{C u}$ & 1.39 & 0.27 & 4.95 & 2228.44 & 2.06 & 6681.37 \\
$\mathbf{Z n}$ & 55.83 & 47.35 & 22.23 & 218.86 & 133.36 & 278.04 \\
$\mathbf{A s}$ & 15.32 & 2.68 & 27.43 & 167.23 & 54.23 & 281.54 \\
$\mathbf{A g}$ & 0.10 & 0.01 & 0.39 & 1.64 & 0.16 & 4.24 \\
$\mathbf{C d}$ & 0.27 & 0.02 & 0.45 & 4.44 & 0.36 & 6.39 \\
$\mathbf{P b}$ & 24.67 & 4.70 & 65.70 & 211.47 & 53.88 & 257.87
\end{tabular}

Notes: Abbreviation: PEL: Permissible exposure limit; USECHH 2000: Use and Standards of Exposure of Chemicals Hazardous to Health (USECHH) Regulations 2000; AM: arithmetic mean; GM: geometric mean; SD: standard deviation.

The mean concentration of the heavy metal found in the toenail are listed in the following order: $\mathrm{Cr}>\mathrm{Fe}>\mathrm{Zn}>\mathrm{Al}$ $>\mathrm{Pb}>\mathrm{Ni}>\mathrm{As}>\mathrm{Mn}>\mathrm{Co}>\mathrm{Cu}>\mathrm{Cd}>\mathrm{Ag}$ (exposed group) and $\mathrm{Cu}>\mathrm{Cr}>\mathrm{Al}>\mathrm{Zn}>\mathrm{Pb}>\mathrm{As}>\mathrm{Fe}>\mathrm{Ni}>\mathrm{Mn}>\mathrm{Cd}>$ $\mathrm{Ag}>\mathrm{Co}$ (non-exposed group) respectively. While the mean concentration of heavy metal found in breathing zone is allocated by the following sequences: $\mathrm{Mn}>\mathrm{Fe}>\mathrm{Cr}>\mathrm{Pb}>\mathrm{As}>\mathrm{Al}>\mathrm{Ni}>\mathrm{Zn}>\mathrm{Cu}>\mathrm{Ag}>\mathrm{Co}(\mathrm{MIG}) ; \mathrm{Fe}>\mathrm{Cr}>\mathrm{Pb}>$ $\mathrm{Al}>\mathrm{As}>\mathrm{Zn}>\mathrm{Mn}>\mathrm{Cu}>\mathrm{Ni}>\mathrm{Ag}>\mathrm{Co}$ (spot welding); and $\mathrm{Cr}>\mathrm{Fe}>\mathrm{Pb}>\mathrm{As}>\mathrm{Al}>\mathrm{Mn}>\mathrm{Zn}>\mathrm{Cu}>\mathrm{Ni}>\mathrm{Co}>\mathrm{Ag}$ (robotic welding). The heavy metals in both toenail and cassette samples show the existence of broad range metal concentrations and this were interpreted by large standard deviations in the data samples. Another important finding revealed that all of the average metals concentration generated from the welding activities that related with MIG, spot 
weld and robotic weld in three plants have exceeded the safe level allowed by USECHH Regulations 2000 except for nickel from robotic weld.

There was a high prevalence of pulmonary diseases in welder's exposure especially to chromium, beryllium, iron, nickel, and aluminium [21]-[24]. In this study, the highest concentration of metal fume is found higher in welder's breathing zone compared to the findings of the other similar study [15], [25]-[27]. Therefore, there is a potential possibility of the welder to experience pulmonary effects due to metal fume exposure in these plants. This exposure may occur due to poor ventilation in welding areas as well as lack of and/or inappropriate wearing of personal protective devices. This study was supported by the previous study where the exposed workers who work near to the point source pose a high risk of heavy metals exposure and have significant heavy metal intoxication even in a low concentration [28].

Toenail specimen, as a recommended biological indicator of heavy metal, were selected to detect the subjects' exposure to 12 types of heavy metals [29]-[31]. The comparison of heavy metal concentrations in toenail from the exposed and non-exposed group is shown in Table 3. Two-independent sample of Mann-Whitney test revealed that there were statistically significant differences $(\mathrm{p}<0.05)$ among exposed and non-exposed groups in a trace element of $\mathrm{Cr}, \mathrm{Zn}, \mathrm{As}, \mathrm{Ag}, \mathrm{Cd}$, and $\mathrm{Pb}$, except for $\mathrm{Al}, \mathrm{Mn}, \mathrm{Fe}, \mathrm{Co}, \mathrm{Ni}$ and $\mathrm{Cu}$. The element concentration of aluminium, manganese, iron, cobalt, nickel, and copper that were found in the non-exposed group is not a surprise since $67 \%$ of the non-exposed group participants is categorised as ever-smoker.

Table 3: Mann Whitney test of toxic metal concentration $(\mathrm{ug} / \mathrm{g})$ in toenail of exposed and non-exposed worker.

\begin{tabular}{cccc}
\hline \multirow{2}{*}{ Metal } & \multicolumn{3}{c}{ Toenail (ug/g) } \\
\cline { 2 - 4 } & Mann-Whitney Test & $\mathbf{Z}$ & $\boldsymbol{p}$-value \\
$\mathrm{Al}$ & 97.0000 & -0.895 & 0.371 \\
$\mathrm{Cr}$ & 25.000 & -3.525 & $0.001^{*}$ \\
$\mathrm{Mn}$ & 95.500 & -0.950 & 0.342 \\
$\mathrm{Fe}$ & 113.000 & -0.311 & 0.756 \\
$\mathrm{Co}$ & 81.000 & -1.480 & 0.139 \\
$\mathrm{Ni}$ & 98.000 & -0.859 & 0.391 \\
$\mathrm{Cu}$ & 81.000 & -1.480 & 0.139 \\
$\mathrm{Zn}$ & 21.000 & -3.458 & $0.001^{*}$ \\
$\mathrm{As}$ & 25.000 & -3.526 & $0.001^{*}$ \\
$\mathrm{Ag}$ & 33.000 & -3.234 & $0.001^{*}$ \\
$\mathrm{Cd}$ & 68.000 & -1.958 & $0.050^{*}$ \\
$\mathrm{~Pb}$ & 59.000 & -2.283 & $0.022^{*}$
\end{tabular}

This habit may influence the number of metals found in the control's body. Despite, it has been suggested that the accumulation of heavy metal in the human body also depends on seafood intake especially shellfish, marine fish and smoking habit [32], [33].

Table 4: Kruskal-Wallis test of heavy metal concentration found in the breathing zone emitted from three different types of welding activities.

\begin{tabular}{ccccccc}
\hline Metal & MIG (n) & Spot weld (n) & Robotic weld (n) & Chi-square & df & p-value \\
\hline $\mathrm{Al}$ & 9 & 2 & 3 & 0.13 & 2 & 0.94 \\
$\mathrm{Cr}$ & 9 & 2 & 3 & 0.43 & 2 & 0.81 \\
$\mathrm{Mn}$ & 9 & 2 & 3 & 4.96 & 2 & 0.08 \\
$\mathrm{Fe}$ & 9 & 2 & 3 & 0.87 & 2 & 0.65 \\
$\mathrm{Co}$ & 9 & 2 & 3 & 2.70 & 2 & 0.23 \\
$\mathrm{Ni}$ & 9 & 2 & 3 & 3.16 & 2 & 0.21 \\
$\mathrm{Cu}$ & 9 & 2 & 3 & 2.19 & 2 & 0.33 \\
$\mathrm{Zn}$ & 9 & 2 & 3 & 0.04 & 2 & 0.98 \\
$\mathrm{As}$ & 9 & 2 & 3 & 2.97 & 2 & 0.23 \\
$\mathrm{Ag}$ & 7 & 2 & 3 & 2.69 & 2 & 0.26 \\
$\mathrm{~Pb}$ & 7 & 2 & 3 & 0.54 & 2 & 0.77 \\
\hline
\end{tabular}

This is proven by even though there is no cadmium concentration was traced in any welding activities area, the existence of cadmium in the toenail of both groups may arise due to the smoking habit as well as food intake [34], [35]. The local study has shown that there is the bioaccumulation of toxic metals of $\mathrm{Cd}, \mathrm{Cu}, \mathrm{Fe}, \mathrm{Mn}, \mathrm{Pb}$ and $\mathrm{Zn}$ in fish samples with the highest average concentration found is Fe [36]. The comparison with the previous study has shown 
that the toenail metal concentration found in welders is lower than these research findings [17], [37]. There are several possible explanations for this result. The discrepancy could be attributed to the welding-type, type of electrode, filler material, base metal and etc as this process has evolved with a wide set of ranging application from deep-sea explorations to the outer space navigations [38], [39]. The data of heavy metal concentration that are emitted from three different welding type are tabulated in Table 4. The current study found that there is no statistically significant difference between the heavy metal discharged from different welding type in three industrial areas. The distribution of metal concentration for three different types of welding has a similar concentration pattern. Thus, the exposure to welding fume among welders in three different plants is assumed to have similar exposure.

The association degree and monotonic relationship of a metal traced element in welder's toenail specimen was measured using Spearman's correlation coefficient analysis and the results are presented in Table 5. This statistical evidence had suggested that the existence of metals in the welder's toenail had a similar anthropogenic source of activity and there are strong significant correlations of toenail metal concentration with one another, with the exception of iron, cobalt, and nickel.

Table 5: Spearman's correlation coefficient $\left(r_{s}\right)$ matrix for pairs of heavy metals found in welder's toenail samples (ug/g).

\begin{tabular}{|c|c|c|c|c|c|c|c|c|c|c|c|c|}
\hline & Al & $\mathrm{Cr}$ & Mn & $\mathbf{F e}$ & Co & $\mathbf{N i}$ & $\mathrm{Cu}$ & Zn & As & Ag & Cd & $\mathbf{P b}$ \\
\hline Al & 1 & & & & & & & & & & & \\
\hline $\mathrm{Cr}$ & -0.48 & 1 & & & & & & & & & & \\
\hline Mn & -0.21 & -0.31 & 1 & & & & & & & & & \\
\hline $\mathbf{F e}$ & 0.31 & -0.23 & -0.02 & 1 & & & & & & & & \\
\hline Co & 0.19 & 0.09 & $-0.48 *$ & 0.15 & 1 & & & & & & & \\
\hline $\mathbf{N i}$ & 0.38 & -0.23 & -0.05 & 0.21 & 0.13 & 1 & & & & & & \\
\hline $\mathrm{Cu}$ & 0.13 & 0.15 & $0.56^{*}$ & -0.04 & -0.31 & 0.07 & 1 & & & & & \\
\hline Zn & 0.08 & 0.10 & 0.39 & -0.02 & -0.13 & -0.00 & $0.77 * *$ & 1 & & & & \\
\hline As & -0.35 & $0.82 * *$ & -0.33 & -0.29 & 0.32 & -0.07 & 0.16 & 0.04 & 1 & & & \\
\hline Ag & $0.39 *$ & 0.11 & -0.13 & 0.09 & 0.17 & 0.32 & 0.12 & 0.07 & 0.28 & 1 & & \\
\hline Cd & 0.10 & -0.11 & $0.38 *$ & -0.24 & -0.28 & 0.07 & 0.23 & 0.03 & 0.01 & 0.36 & 1 & \\
\hline $\mathbf{P b}$ & 0.12 & 0.04 & 0.27 & -0.24 & -0.16 & 0.02 & $0.47 *$ & 0.25 & 0.19 & $0.44 *$ & $0.85 * *$ & 1 \\
\hline
\end{tabular}

Correlations between airborne and toenail concentrations for eleven metals were investigated using Spearman's correlation coefficient analysis and the result was bold and expressed in Table 6. Results showed that the correlation coefficients range from 0.11 to 0.59 . There was a moderate relationship of silver in toenail and workplace environment, while, a strong relationship is found in manganese, iron, cobalt, and lead between a worker who exposed to carcinogenic metals in automotive-related component industries and their toenail concentrations. The strong negative correlation indicates that the anthropogenic origin source of metal in toenail does correlate with the workplace welding fumes emission.

Table 6: Spearman's correlation coefficient $\left(r_{s}\right)$ in measuring heavy metal found in welder's toenail (ug/g) and heavy metals captured in the workplace environment $\left(\mathrm{mg} / \mathrm{m}^{3}\right)$.

\begin{tabular}{|c|c|c|c|c|c|c|c|c|c|c|c|c|}
\hline \multirow{2}{*}{\multicolumn{2}{|c|}{ Metals }} & \multicolumn{11}{|c|}{$r_{s}$ Toenail Specimen $(\mathrm{ug} / \mathrm{g})$} \\
\hline & & Al & $\mathrm{Cr}$ & Mn & Fe & Co & $\mathbf{N i}$ & $\mathrm{Cu}$ & $\mathbf{Z n}$ & As & Ag & $\mathbf{P b}$ \\
\hline \multirow{11}{*}{ 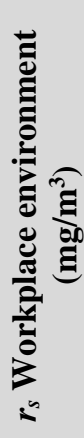 } & Al & -0.15 & -0.12 & 0.23 & 0.14 & -0.16 & 0.10 & 0.37 & 0.21 & -0.13 & 0.12 & 0.41 \\
\hline & $\mathrm{Cr}$ & 0.04 & -0.11 & -0.21 & -0.32 & 0.30 & 0.48 & -0.03 & -0.22 & -0.00 & 0.08 & 0.24 \\
\hline & Mn & 0.31 & 0.06 & -0.51 & 0.02 & 0.53 & 0.46 & $-0.64 *$ & -0.49 & 0.08 & 0.11 & $-0.61 *$ \\
\hline & Fe & 0.06 & -0.00 & -0.27 & 0.49 & 0.17 & 0.02 & -0.45 & $-0.60 *$ & 0.02 & 0.17 & -0.24 \\
\hline & Co & -0.27 & -0.05 & $0.62 *$ & 0.09 & $-0.53 *$ & -0.17 & $0.59 *$ & $0.59 *$ & -0.08 & -0.01 & 0.44 \\
\hline & $\mathbf{N i}$ & 0.25 & 0.10 & 0.30 & 0.28 & -0.04 & -0.29 & 0.17 & 0.23 & 0.06 & -0.52 & -0.20 \\
\hline & $\mathrm{Cu}$ & 0.20 & -0.10 & 0.10 & 0.21 & 0.04 & -0.11 & -0.18 & -0.13 & -0.06 & 0.16 & -0.27 \\
\hline & $\mathbf{Z n}$ & -0.06 & -0.18 & 0.32 & 0.06 & -0.24 & 0.08 & 0.31 & 0.25 & -0.19 & 0.19 & 0.40 \\
\hline & As & 0.35 & -0.29 & -0.17 & -0.05 & 0.30 & 0.39 & -0.28 & -0.40 & -0.19 & 0.09 & -0.06 \\
\hline & Ag & 0.29 & -0.08 & 0.27 & 0.34 & 0.07 & -0.18 & 0.40 & 0.30 & -0.09 & -0.34 & -0.15 \\
\hline & $\mathbf{P b}$ & 0.04 & -0.06 & -0.21 & 0.41 & 0.09 & -0.08 & -0.27 & -0.11 & -0.05 & 0.21 & $-0.59 *$ \\
\hline
\end{tabular}

Notes:* Correlation is significant at the 0.05 level (2-tailed), and **: Correlation is significant at the 0.01 level (2-tailed).

\section{Conclusion}

In summary, the results indicate that the heavy metals concentration found in the toenail of the exposed and nonexposed group is statistically difference except for $\mathrm{Al}, \mathrm{Mn}, \mathrm{Fe}, \mathrm{Co}, \mathrm{Ni}$ and $\mathrm{Cu}$. The existence of these constituents in the 
toenail may portray from the smoking habit as well as possible due to seafood intake. One of the more significant findings from this study is that the metal fume exposure generated from different welding types in these three plant has shown a similar exposure to the welders. Furthermore, a medium to a very strong relationship of chemical concentration was found in both work environment and toenail of heavy metals except for three metals ( $\mathrm{Fe}, \mathrm{Co}$ and $\mathrm{Ni}$ ). Thus, for any kind of welding type, more attention needs to be considered for conducive working conditions, specifically on having proper ventilation at the workplace as well as providing suitable protective personal devices to the exposed group.

\section{Conflict of Interest}

The authors firmly declare that there are no conflicts of interest related to this work.

\section{Acknowledgement}

This project was financially supported by the Fundamental Research Grant Scheme (FRGS) vote 1539 under the Malaysian Ministry of Education. We are thankful to all participant that were involved for his or her endless support and cooperation during the research study.

\section{References}

[1] Jaishankar, M., Tseten, T., Anbalagan, N., Mathew, B. B., \& Beeregowda, K. N. (2014). Toxicity, mechanism and health effects of some heavy metals. Interdisciplinary Toxicology, 7, 60-72.

[2] Yadav, M., Gupta, R., \& Sharma, R. K. (2019). Green and Sustainable Pathways for Wastewater Purification. Advances in Water Purification Techniques, Elsevier, 360.

[3] Tchounwou, P. B., Yedjou, C. G., Patlolla, A. K., \& Sutton, D. J. (2012). Heavy Metal Toxicity and the Environment, 101.

[4] Järup, L. (2003). Hazards of heavy metal contamination. British Medical Bulletin, 68, 167-82.

[5] Jan, A., Azam, M., Siddiqui, K., Ali, A., Choi, I., \& Haq, Q. (2015). Heavy Metals and Human Health: Mechanistic Insight into Toxicity and Counter Defense System of Antioxidants. International Journal of Molecular Sciences, 16, 29592-29630.

[6] Paiman, N. A., Hariri, A., Masood, I., Noor, A., Yusof, K. H., Abdullah, S., Idris, A. F., Afandi, M. A. M., Asmuin, N. Z., \& Leman, A. M. (2018). Development of Neurobehavioral Deterioration Risk Prediction Model for Welder: A Proposed Study. International Journal of Integrated Engineering, 10, 5.

[7] ElSafty, A. (2014). Health Implications of Heavy Metal Overload. Occupational Medicine \& Health Affairs, 02, 01.

[8] Qu, C. S., Ma, Z. W., Yang, J., Liu, Y., Bi, J., \& Huang, L. (2012). Human Exposure Pathways of Heavy Metals in a Lead-Zinc Mining Area, Jiangsu Province, China. PLoS One, 7, e46793.

[9] Kile, M. L., Houseman, E. A., Breton, C. V., Quamruzzaman, Q., Rahman, M., Mahiuddin, G., Christiani, D. C. (2007). Association between total ingested arsenic and toenail arsenic concentrations. Journal of Environmental Science and Health, Part A, 42, 1827-34.

[10] Sanders, A. P., Miller, S. K., Nguyen, V., Kotch, J. B., \& Fry, R. C. (2014). Toxic metal levels in children residing in a smelting craft village in Vietnam: a pilot biomonitoring study. BMC Public Health, 14, 114.

[11] Dancey, C. P. \& Reidy, J. (2014). Statistics Without Maths for Psychology: Using Spss for Windows. PrenticeHall.

[12] Bradshaw, L. M., Fishwick, D., Slater, T., \& Pearce, N. (1998). Chronic bronchitis, work related respiratory symptoms, and pulmonary function in welders in New Zealand. Occupational and Environmental Medicine, 55, $150-154$.

[13] Bakri, S. F. Z., Hariri, A., Ismail, M., Abdullah, S., \& Kassim, N. I. (2018). Evaluation of Respiratory Symptoms, Spirometric Lung Patterns and Metal Fume Concentrations among Welders in Indoor Air-Conditioned Building at Malaysia. International Journal of Integrated Engineering: Special issue, 10, 109-121.

[14] Hariri, A., Noor, N. M., Paiman, N. A., Zaidi, A. M. A., \& Bakri, S. F. Z. (2017). Heavy metals found in the breathing zone, toenails and lung function of welders working in an air-conditioned welding workplace. International Journal of Occupational Safety and Ergonomics, 24, 1-6.

[15] Schoonover, T., Conroy, L., Lacey, S., \& Plavka, J. (2011). Personal exposure to metal fume, NO2, and O3 among production welders and non-welders. Industrial Health, 49, 63-72.

[16] Korczynski, R. E. (2000). Occupational health concerns in the welding industry. Applied Occupational and Environmental Hygiene, 15, 936-45.

[17] Grashow, R., Zhang, J., Fang, S. C., Weisskopf, M. G., Christiani, D. C., \& Cavallari, J. M. (2014). Toenail metal concentration as a biomarker of occupational welding fume exposure. Journal of Occupational and Environmental Hygiene, 11, 397-405. 
[18] Bakri, S. F. Z., Hariri, A., \& Ismail, M. (2019). Metal fumes toxicity and its association with lung health problems among welders in automotive industry. Journal of Physics: Conference Series, 1150, 012001.

[19] Hariri, A., Yusof, M. Z. M., \& Paiman, N. A. (2015). Lung Functions of Welders in Three Automotive Related Industries in Malaysia. Journal of Industrial and Intelligent Information, 3, 15-19.

[20] Backman, H., Eriksson, B., Hedman, L., Stridsman, C., Jansson, S. A., Sovijärvi, A., Lindberg, A., Rönmark, E., Lundbäck, Bo. (2016). Restrictive spirometric pattern in the general adult population: Methods of defining the condition and consequences on prevalence. Respiratory Medicine, 120, 116-123.

[21] Krantz, A., \& Dorevitch, S. (2004). Metal exposure and common chronic diseases: a guide for the clinician, Disease-a-Month, 50, 220-62.

[22] Weiss, T., Pesch, B., Lotz, A., Gutwinski, E., Gelder, R. V., Punkenburg, E., Kendzia, B., Gawrych, K., Lehnert, M., Heinze, E., Hartwig, A., Käfferlein, H. U., Hahn, J., Brüning, T. (2013). Levels and predictors of airborne and internal exposure to chromium and nickel among welders-Results of the WELDOX study. International Journal of Hygiene and Environmental Health, 216, 175-183.

[23] Antonini, J. M., Badding, M. A., Meighan, T. G., Keane, M., Leonard, S. S., \& Roberts, J. R. (2014). Evaluation of the Pulmonary Toxicity of a Fume Generated from a Nickel-, Copper-Based Electrode to be Used as a Substitute in Stainless Steel Welding. Environmental Health Insight, 8, 11-20.

[24] Rossbach, B., Buchta, M., Csanády, G. A., Filser, J. G., Hilla, W., Windorfer, K., Stork, J., Zschiesche, W., Gefeller, O., Pfahlberg, A., Schaller, K. H., Egerer, E., Pinzón, L. C. E., \& Letzel, S. (2006). Biological monitoring of welders exposed to aluminium. Toxicology Letters, 162, 239-245.

[25] Golbabaei, F., Seyedsomea, M., Ghahri, A., Shirkhanloo, H., Khadem, M., Hassani, H., Sadeghi, N., \& Dinari, B. (2012). Assessment of welders exposure to carcinogen metals from manual metal arc welding in gas transmission pipelines, Iran. Iranian Journal of Public Health, 41, 61-70.

[26] Koh, D. H., Kim, J. I., Kim, K. H., \& Yoo, S. W. (2015). Welding fume exposure and chronic obstructive pulmonary disease in welders, Occupational Medicine, 65, 1.

[27] Buonanno, G., Morawska, L., \& Stabile L. (2011). Exposure to welding particles in automotive plants. Journal of Aerosol Science, 42, 295-304.

[28] Al-Bakheet, S. A., Attafi, I. M., Maayah, Z. H., Abd-Allah, A. R., Asiri, Y. A., \& Korashy, H. M. (2013). Effect of long-term human exposure to environmental heavy metals on the expression of detoxification and DNA repair genes. Environmental Pollution, 181, 226-232.

[29] Garland, M. Morris, J. S., Rosner, B. A., Stampfer, M. J., Spate, V. L., Baskett, C. J., Willett, W. C., \& Hunter, D. J. (1993). Toenail trace element levels as biomarkers: reproducibility over a 6-year period. Cancer Epidemiology, Biomarkers Prevention, 2, 493-7.

[30] Goulle, J. P., Saussereau, E., Mahieu, L., Bouige, D., Groenwont, S., Guerbet, M., \& Lacroix, C. (2009). Application of Inductively Coupled Plasma Mass Spectrometry Multielement Analysis in Fingernail and Toenail as a Biomarker of Metal Exposure. Journal of Analytical Toxicology, 33, 92-98.

[31] Bakri, S. F. Z., Hariri, A., Ma'arop, N. F., \& Hussin, N. S. A. W. (2017). Toenail as Non-invasive Biomarker in Metal Toxicity Measurement of Welding Fumes Exposure - A Review. IOP Conference Series: Materials Science and Engineering, 165, 012019.

[32] Asaduzzaman, K., Khandaker, M. U., Baharudin, N. A., Amin, Y. M., Farook, M. S., Bradley, D. A., \& Mahmoud, O. (2017). Heavy metals in human teeth dentine: A bio-indicator of metals exposure and environmental pollution. Chemosphere, 176, 221-230.

[33] Baki, M. A., Hossain, M. M., Akter, J., Quraishi, S., Shojib, M. F. H., Ullah, A. K. M. A., \& Khan, M. F. (2018). Concentration of heavy metals in seafood (fishes, shrimp, lobster and crabs) and human health assessment in Saint Martin Island, Bangladesh. Ecotoxicology and Environmental Safety, 159, 153-163.

[34] Ashraf, M. W. (2012). Levels of heavy metals in popular cigarette brands and exposure to these metals via smoking. Scientific World Journal, 2012, 729430.

[35] El-Samad, M. A. \& Hanafi, H. A. (2017). Analysis of toxic heavy metals in cigarettes by Instrumental Neutron Activation Analysis. Journal of Taibah University for Science, 11, 822-829.

[36] Rosli, M. N. R., Samat, S. B., Yasir, M. S., \& Yusof, M. F. M. (2018). Analysis of Heavy Metal Accumulation in Fish at Terengganu Coastal Area, Malaysia. Sains Malaysiana, 47, 1277-1283.

[37] Grashow, R., Zhang, J., Fang, S. C., Weisskopf, M. G., Christiani, D. C., Kile, M. L., \& Cavallari, J. M. (2014). Inverse association between toenail arsenic and body mass index in a population of welders. Environmental Research, 131, 131-133.

[38] Yoon, C. S., Paik, N. W., \& Kim, J. H. (2003). Fume generation and content of total chromium and hexavalent chromium in flux-cored arc welding. The Annals of Occupational Hygiene, 47, 671-80.

[39] Mohideen, S. R., \& Zaidi, A. M. A. (2010). Influence of Post Weld Heat Treatment on the HAZ of Low Alloy Steel Weldments. International Journal of Integrated Engineering, 2, $7-12$. 